\title{
EFEKTIVITAS DONEPEZIL TERHADAP FUNGSI KOGNITIF PASIEN TUMOR INTRAKRANIAL PASCAOPERASI
}

\author{
EFFECTIVITY OF DONEPEZIL IN COGNITIVE FUNCTION OF POSTOPERATIVE \\ INTRACRANIAL TUMOUR PATIENTS
}

Yusril Harun, * Yunni Diansari, * Selly Marisdina, * Yuli Felistia*

\section{ABSTRACT}

Introduction: There is still a lack of effective therapy in improving cognitive dysfunction in intracranial tumour patients after surgery. Donepezil is an acetylcholinesterase inhibitor that has been a therapy of Alzheimer's disease and has a significant effect on improving cognitive function.

Aim: To determine the effectiveness of donepezil on cognitive function in patients with postoperative intracranial tumours.

Methods: A clinical, randomized, double-blind study was conducted on postoperative intracranial tumour patients categorized into two groups (donepezil and placebo). The intervention was donepezil $5 \mathrm{mg}$ once a day for three months. For assessment of cognitive function, Mini-Mental State Examination (MMSE) and Indonesian Version of Montreal Cognitive Assessment (MoCA-Ina) was checked at weeks 0 (baseline), 4 (end of the first month), 8 (end of the second month), and 12 (end of the third month). Data were analyzed using SPSS 22.

Results: Twenty patients, equally distributed in two groups, were included in the study. Compared to baseline, MMSE and MoCA-Ina scores in the donepezil group increased significantly on the second and third month ( $p<0.001)$. There was a remarkable difference in cognitive function between two groups on the third month based on MMSE and MoCA-Ina scores ( $p=0.027$ and 0.024, respectively). At post-intervention, orientation and recall domain in MMSE showed marked improvement, while visuospatial and delayed recall domain experienced as well in MoCA-Ina. There were no significant side effects of donepezil.

Discussion: This results can be considered for administration of donepezil in patients with intracranial tumours after surgery with impaired cognitive function.

Keywords: Cognitive function, donepezil, intracranial tumour, MMSE, MoCA-Ina, surgery

\section{ABSTRAK}

Pendahuluan: Saat ini belum ada terapi yang efektif dalam memperbaiki gangguan fungsi kognitif pada pasien tumor intrakranial pascaoperasi. Donepezil merupakan inhibitor asetilkolinesterase yang telah menjadi terapi dari penyakit Alzheimer dan memiliki efek yang bermakna dalam memperbaiki fungsi kognitif.

Tujuan: Mengetahui efektivitas donepezil terhadap fungsi kognitif pasien tumor intrakranial pascaoperasi.

Metode: Studi uji klinis, acak, tersamar ganda dilakukan pada pasien tumor intrakranial pascaoperasi dengan gangguan kognitif yang terbagi dalam dua kelompok (donepezil dan plasebo). Intervensi yang dilakukan berupa pemberian donepezil 5mg satu kali sehari selama 3 bulan. Evaluasi fungsi kognitif menggunakan Mini Mental State Examination (MMSE) dan Montreal Cognitive Assessment Versi Indonesia (MoCA-Ina) pada minggu 0 (awal), 4 (akhir bulan ke-1), 8 (akhir bulan ke-2), dan 12 (akhir bulan ke-2). Data dianalisis menggunakan perangkat SPSS 22.

Hasil: Sebanyak 20 subjek yang terbagi sama pada dua kelompok diikutsertakan pada penelitian ini. Dibandingkan dengan kondisi awal, nilai MMSE dan MoCA-Ina pada kelompok donepezil meningkat secara signifikan pada bulan ke-2 dan ke-3 $(p<0,001)$. Terdapat perbedaan bermakna fungsi kognitif antara kelompok terapi dengan placebo pada bulan ke-3 berdasarkan nilai MMSE $(\mathrm{p}=0,027)$ dan MoCA-Ina $(\mathrm{p}=0,024)$. Domain pada MMSE yang mengalami perbaikan bermakna setelah terapi donepezil adalah orientasi dan recall, sedangkan pada MoCA-Ina adalah domain visuospasial dan delayed recall. Tidak didapatkan efek samping donepezil yang bermakna.

Diskusi: Hasil penelitian ini dapat menjadi pertimbangan dalam pemberian donepezil pada pasien dengan tumor intrakranial pascaoperasi yang memiliki gangguan fungsi kognitif.

Kata kunci: Donepezil, fungsi kognitif, MMSE, MoCA-Ina, operasi, tumor intrakranial

*Bagian Neurologi FK Universitas Sriwijaya/RSUP Dr. Moh. Hoesin, Palembang. Koresponsdensi: yusneuro@yahoo.co.id.

\section{PENDAHULUAN}

Insidens dan prevalensi dari tumor intrakranial meningkat dalam beberapa tahun terakhir ${ }^{1}$ yang sebagian besar $(>80 \%)$ kasus, baik primer maupun metastasis dijumpai adanya gangguan fungsi kognitif. ${ }^{2}$ Tucha dkk mendapatkan $>90 \%$ pasien dengan tumor otak memiliki gangguan paling sedikit satu dari area fungsi kognitif. Gangguan fungsi 
eksekutif ditemukan pada 78\% kasus, sedangkan gangguan memori dan atensi ditemukan pada lebih dari $60 \%$ kasus. $^{1}$

Pada penelitian awal yang dilakukan di RSUP Dr. Mohammad Hoesin, Palembang (RSMH) didapatkan gangguan fungsi kognitif berdasarkan pemeriksaan Montreal Cognitive Assessment Versi Indonesia (MoCA-Ina), yaitu sebesar 81,5\% pada tumor intrakranial primer dan $86,6 \%$ pada tumor metastasis. ${ }^{3}$ Gangguan fungsi kognitif pada tumor intrakranial dapat disebabkan oleh massa tumor dan tata laksana yang diberikan, meliputi tindakan pembedahan, kemoterapi serta radioterapi. ${ }^{1,4}$

Sampai saat ini masih belum adanya obat yang diberikan sebagai standar terapi untuk perbaikan fungsi kognitif pada pasien dengan tumor intrakranial ataupun pascaterapi seperti pembedahan, radioterapi atau kemoterapi. Beberapa studi dengan pemberian methylphenidate dan modafinil menunjukkan hasil yang kurang memuaskan. ${ }^{4}$ Beberapa tahun terakhir banyak penelitian yang menilai efektivitas pemberian donepezil terhadap fungsi kognitif.

Donepezil merupakan inhibitor asetilkolinesterase yang disetujui oleh Food and Drug Administration (FDA) dan telah menjadi terapi dari penyakit alzheimer. Donepezil bekerja terutama pada reseptor muskarinik yang memiliki peran dalam fungsi kognitif. 5 Studi sebelumnya sudah banyak yang dilakukan untuk melihat peran donepezil pada pasien dengan tumor intrakranial pascaradioterapi dan kemoterapi dan didapatkan hasil yang bermakna, tetapi masih kurangnya data pada pasien yang hanya dilakukan tindakan pembedahan saja. ${ }^{6-7} \mathrm{Hal}$ ini mengingat belum semua fasilitas kesehatan di Indonesia yang dapat melakukan tindakan radioterapi dan kemoterapi, selain juga pasien sering menolak tindakan lanjutan pascaoperasi. Namun dengan mempertimbangkan bahwa kemoterapi dan radioterapi dapat menimbulkan gangguan kognitif, maka penelitian ini khusus spesifik menilai gangguan pascapengambilan massa tumor.

\section{TUJUAN}

Mengetahui efektivitas donepezil terhadap fungsi kognitif pada pasien dengan tumor intrakranial pascaoperasi di RSMH, Palembang.

\section{METODE}

Penelitian dilakukan di RSMH, Palembang, dari bulan Juli sampai Desember 2018 dengan pendekatan studi uji klinis, acak, dan tersamar ganda (double blinded, randomized controlled trial) terhadap pasien tumor primer intrakranial dengan gangguan fungsi kognitif.

Kriteria inklusi adalah subjek berusia 18-65 tahun, mempunyai hasil histopatologi tumor primer intrakranial, belum dilakukan kemoterapi atau radioterapi, serta bersedia menandatangani informed consent. Usia dikelompokkan menjadi usia muda ( $<30$ tahun), menengah (30-60 tahun), dan tua ( $>60$ tahun). Khusus usia $>60$ tahun dibuat untuk menilai adanya faktor perancu lain, seperti mild cognitive impairment.

Gangguan fungsi kognitif pada evaluasi awal dinilai pascaoperasi berdasarkan nilai abnormal dari pemeriksaan Mini Mental State Examination (MMSE) dan MoCA-Ina. Adapun kriteria eksklusi adalah pasien yang sedang menggunakan donepezil, memantin, metilfenidat, gingko biloba, dan modafinil, serta riwayat penyakit stroke atau penyakit yang menyebabkan gangguan kognitif lainnya.

Kelompok kontrol diberikan plasebo berupa kapsul yang warna dan jenisnya dibuat mirip dengan donepezil, satu kali setiap hari selama 3 bulan. Adapun kelompok perlakuan diberikan donepezil 5mg satu kali sehari selama 3 bulan. Evaluasi dilakukan pada minggu ke-4, ke-8, dan ke-12 yang meliputi anamnesis untuk mengetahui efek samping obat, pemeriksaan fisik neurologis, serta pemeriksaan MoCA-Ina dan MMSE. ${ }^{8}$

Pemeriksaan MoCA digunakan sebagai skrining awal untuk mendeteksi gangguan fungsi kognitif yang meliputi domain atensi, konsentrasi, fungsi eksekutif, memori, bahasa, kemampuan visuospasial, abstrak, kalkulasi, dan orientasi. Pemeriksaan ini digunakan secara luas diseluruh dunia dan sudah divalidasi ke dalam bahasa Indonesia (MoCA-Ina). Subjek dinyatakan normal jika skor $\geq 26$; gangguan kognitif ringan (skor 18 25), gangguan kognitif sedang (skor 10-17), dan gangguan kognitif berat $($ skor $\leq 9) .{ }^{9}$ 
Skrining gangguan fungsi kognitif yang lebih sederhana adalah MMSE yang meliputi pemeriksaan visuospasial/eksekutif, memori, orientasi, atensi, penamaan, abstraksi, delayed recall, dan bahasa. Pengkategorian hasil MMSE adalah $\geq 24$ (normal); 19-23 (gangguan kognitif ringan); 10-18 (gangguan kognitif sedang); dan $\leq 9$ (gangguan kognitif berat). ${ }^{10}$

Penelitian ini sudah mendapat persetujuan etik dari RSMH/Fakultas Kedokteran Universitas Sriwijaya No.87/kepkrsmhfkunsri/2018. Dilakukan analisis univariat dan bivariat menggunakan uji paired t-test, uji Wilcoxon, uji Mann-Whitney, serta independent t-test. Randomisasi dilakukan secara acak dengan bantuan software untuk randomisasi, peneliti utama tidak mengetahui obat yang diberikan kepada subjek. Adapun pemeriksaan fungsi kognitif dilakukan oleh 1 peneliti yang sama terhadap semua subjek dari awal hingga akhir penelitian.

Pada saat awal informed consent seluruh subjek diinformasikan tentang efek samping yang mungkin terjadi, seperti mual, muntah, diare, hilangnya nafsu makan, penurunan berat badan, serta sakit kepala untuk segera dilaporkan kepada tim peneliti. Pemantauan efek samping dilakukan perbulan saat pasien kontrol atau via telepon sesuai kondisi pasien.

\section{HASIL}

Didapatkan 20 subjek yang dibagi menjadi kelompok terapi donepezil dan kelompok kontrol (plasebo) masing-masing 10 subjek. Rerata usia keseluruhan subjek adalah $44+8,36$ tahun, mayoritas subjek adalah perempuan dengan jenis tumor meningioma. Lamanya jarak waktu antara operasi dengan pemeriksaan fungsi kognitif adalah 3-11 bulan. Tidak terdapat perbedaan karakteristik pada kedua kelompok (Tabel 1). Pemantauan yang dilakukan sepanjang penelitian via telepon atau kontrol langsung di poliklinik menunjukkan tidak ada subjek yang melaporkan keluhan efek samping dari terapi yang diberikan.

Data awal didapatkan semua subjek pada kelompok donepezil mengalami gangguan atensi, kalkulasi, dan bahasa pada pemeriksaan MMSE dan visuospasial, atensi, bahasa, dan delayed recall pada pemeriksaan MoCA-Ina (Tabel 1). Adapun gangguan orientasi, atensi, recall, dan bahasa paling banyak dijumpai pada tumor di lobus temporal (Tabel 2).

Tabel 3 menunjukkan adanya peningkatan rerata nilai MMSE dan MoCA-Ina yang bermakna mulai dari bulan ke-2 pascapemberian donepezil. Namun jika dibandingkan dengan plasebo (Tabel 4), didapatkan peningkatan skor MMSE dan MoCA-Ina yang bermakna pascapemberian donepezil di bulan ke-3 ( $\mathrm{p}=0,027$ dan $\mathrm{p}=0,024)$.

Tabel 5 menunjukkan adanya perbedaan yang bermakna pada domain orientasi dan recall sebelum dan setelah terapi donapezil ( $\mathrm{p}=0,017$ dan $\mathrm{p}=0,06$ ). Terdapat perbaikan skor MMSE yang bermakna pada pemberian donapezil dibandingkan dengan plasebo.

Adapun hasil analisis penilaian MoCA-Ina didapatkan perbedaan yang bermakna pada domain visuospasial dan delayed recall sebelum dan setelah terapi donapezil (Tabel 6).

\section{PEMBAHASAN}

Didapatkan 20 subjek tumor intrakranial primer dengan rerata usia keseluruhan subjek adalah $44 \pm 8,36$ tahun, mayoritas perempuan, dan jenis tumor meningioma. Hal ini sesuai dengan data di Departemen Patologi Anatomi FKUI/RSUPN Dr. Cipto Mangunkusumo, meningioma merupakan tumor intrakranial yang paling banyak ditemukan, yaitu $58,5 \%$ yang diikuti glioma $23,7 \% .{ }^{11}$ Data ini juga sesuai dengan RS Kanker Nasional Dharmais, Jakarta, meningioma merupakan tumor primer tertinggi $(37,2 \%)$ yang diikuti oleh glioma. ${ }^{14}$ Adapun mayoritas subjek perempuan pada penelitian ini juga sesuai dengan penelitian di RSMH, yaitu sebanyak $60 \%$ perempuan. $^{3}$

Distribusi subjek penelitian ini hampir sama pada awal pemeriksaan MMSE, yaitu kedua kelompok menunjukkan gangguan paling banyak terjadi pada komponen atensi dan kalkulasi, serta bahasa. Demikian pula sebaran data ini tidak jauh berbeda pada pemerikaan MoCA-Ina awal, didapatkan paling banyak gangguan visuospasial/ eksekutif, atensi, bahasa, dan delayed recall pada kedua kelompok.

Pada penelitian ini tidak ada subjek berusia $>60$ tahun, sehingga dianggap tidak ada yang mengalami 
Tabel 1. Distribusi berdasarkan Karakteristik Subjek $(n=20)$

\begin{tabular}{|c|c|c|c|c|}
\hline \multirow[b]{2}{*}{ Variabel } & \multicolumn{2}{|c|}{ Kelompok Terapi } & \multirow[b]{2}{*}{ n (\%) } & \multirow{2}{*}{$\mathrm{p}^{*}$} \\
\hline & $\begin{array}{c}\text { Donapezil } \\
\text { n (\%) }\end{array}$ & $\begin{array}{c}\text { Plasebo } \\
\text { n (\%) }\end{array}$ & & \\
\hline Usia & & & & 1 \\
\hline - $<30$ tahun & $0(0)$ & $1(10)$ & $1(5)$ & \\
\hline - 30-60 tahun & $10(100)$ & $9(90)$ & $19(95)$ & \\
\hline - $>60$ tahun & $0(0)$ & $0(0)$ & $0(0)$ & \\
\hline Jenis Kelamin & & & & 0,582 \\
\hline - Laki-laki & $3(30)$ & $1(10)$ & $4(20)$ & \\
\hline - Perempuan & $7(70)$ & $9(90)$ & $16(80)$ & \\
\hline Jenis Tumor & & & & 0,317 \\
\hline - Meningioma & $10(100)$ & $7(70)$ & $17(85)$ & \\
\hline - Astrositoma & $0(0)$ & $1(10)$ & $1(5)$ & \\
\hline - Hemangioma & $0(0)$ & $1(10)$ & $1(5)$ & \\
\hline - Glioma & $0(0)$ & $1(10)$ & $1(5)$ & \\
\hline Lokasi Tumor & & & & 0,987 \\
\hline - Frontal & $3(30)$ & $2(20)$ & $5(25)$ & \\
\hline - Temporal & $3(30)$ & $4(40)$ & $7(35)$ & \\
\hline - Parietal & $2(20)$ & $2(20)$ & $4(20)$ & \\
\hline - Frontotemporal & $1(10)$ & $1(10)$ & $2(10)$ & \\
\hline - Temporoparietal & $1(10)$ & $1(10)$ & $2(10)$ & \\
\hline MMSE Awal** & & & & 0,715 \\
\hline - Orientasi & $8(80)$ & $8(80)$ & $16(80)$ & \\
\hline - Registrasi & $3(30)$ & $0(0)$ & $3(15)$ & \\
\hline $\begin{array}{l}\text { - Atensi \& } \\
\text { kalkulasi }\end{array}$ & $10(100)$ & $10(100)$ & $20(100)$ & \\
\hline - Recall & $9(90)$ & $10(100)$ & $19(15,8)$ & \\
\hline - Bahasa & $10(100)$ & $10(100)$ & $20(100)$ & \\
\hline MoCA-Ina Awal** & & & & 0,638 \\
\hline - Visuospasial & $10(100)$ & $10(100)$ & $20(100)$ & \\
\hline - Penamaan & $5(50)$ & $8(80)$ & $13(65)$ & \\
\hline - Atensi & $10(100)$ & $10(100)$ & $20(100)$ & \\
\hline - Bahasa & $10(100)$ & $10(100)$ & $20(100)$ & \\
\hline - Abstraksi & $9(90)$ & $9(90)$ & $18(90)$ & \\
\hline - Delayed recall & $10(100)$ & $10(100)$ & $20(100)$ & \\
\hline - Orientasi & $8(80)$ & $8(80)$ & $16(80)$ & \\
\hline
\end{tabular}

*Uji Fisher's Exact; $\mathrm{p}<0,05$ bermakna; ${ }^{* *}$ Satu subjek dapat memiliki gangguan pada lebih dari 1 domain; MMSE: Mini Mental State Examination; MoCA-Ina: Montreal Cognitive Assessment Versi Indonesia.

gangguan fungsi kognitif akibat pengaruh usia. untuk proses fungsi kognitif. ${ }^{12}$ Studi acak lainnya Penelitian ini mendapatkan efek pemberian donepezil yang bermakna terhadap perbaikan skor MMSE dan MoCA-Ina mulai bulan ke-2. Selain efek langsung yang diketahui pada fungsi neuron, donepezil juga pada tumor otak primer menunjukkan peningkatan domain atensi dan memori verbal yang bermakna pada kelompok perlakuan setelah diberikan selama 4 minggu. ${ }^{10}$ 
Tabel 2. Distribusi Gangguan Kognitif (Sebelum Perlakuan) Berdasarkan Lokasi Tumor (n=20)

\begin{tabular}{|c|c|c|c|c|c|}
\hline Variabel & $\begin{array}{c}\text { Frontal } \\
\mathbf{n}(\%)\end{array}$ & $\begin{array}{c}\text { Temporal } \\
\text { n(\%) }\end{array}$ & $\begin{array}{c}\text { Parietal } \\
\mathbf{n}(\%)\end{array}$ & $\begin{array}{c}\text { Frontotemporal } \\
\mathbf{n}(\%)\end{array}$ & $\begin{array}{c}\text { Temporoparietal } \\
\text { n(\%) }\end{array}$ \\
\hline \multicolumn{6}{|l|}{ MMSE** } \\
\hline - Orientasi & $4(80)$ & $6(85)$ & $2(50)$ & $2(100)$ & $2(100)$ \\
\hline - Registrasi & $1(20)$ & $0(0)$ & $2(50)$ & $0(0)$ & $0(0)$ \\
\hline - Atensi & $5(100)$ & $7(100)$ & $4(100)$ & $2(100)$ & $2(100)$ \\
\hline - Recall & $5(100)$ & $6(85)$ & $4(100)$ & $2(100)$ & $2(100)$ \\
\hline - Bahasa & $5(100)$ & $7(100)$ & $4(100)$ & $2(100)$ & $2(100)$ \\
\hline \multicolumn{6}{|l|}{ MoCA-Ina** } \\
\hline - Visuospasial & $5(100)$ & $7(100)$ & $4(100)$ & $2(100)$ & $2(100)$ \\
\hline - Penamaan & $4(80)$ & $5(71)$ & $2(50)$ & $0(0)$ & $2(100)$ \\
\hline - Atensi & $5(100)$ & $7(100)$ & $4(100)$ & $2(100)$ & $2(100)$ \\
\hline - Bahasa & $5(100)$ & $7(100)$ & $4(100)$ & $2(100)$ & $2(100)$ \\
\hline - Abstraksi & $3(60)$ & $6(85)$ & $4(100)$ & $2(100)$ & $2(100)$ \\
\hline - Delayed recall & $5(100)$ & $7(71)$ & $4(100)$ & $2(100)$ & $2(100)$ \\
\hline - Orientasi & $4(80)$ & $6(85)$ & $2(50)$ & $2(100)$ & $2(100)$ \\
\hline
\end{tabular}

Tabel 3. Perbedaan Efek Pemberian Donepezil terhadap Fungsi Kognitif (n=20)

\begin{tabular}{|c|c|c|c|c|}
\hline Waktu Terapi & $\begin{array}{c}\text { MMSE } \\
\operatorname{Rerata} \pm \text { SD }\end{array}$ & $p^{*}$ & $\begin{array}{l}\text { MoCA-Ina } \\
\text { Rerata } \pm \text { SD }\end{array}$ & $p^{*}$ \\
\hline Bulan ke-0 & $14,60 \pm 4,37$ & 0,138 & $9,30 \pm 3,65$ & 0,309 \\
\hline Bulan ke-1 & $15,10 \pm 4,22$ & & $9,70 \pm 3,52$ & \\
\hline Bulan ke-0 & $14,60 \pm 4,37$ & $<0,001$ & $9,30 \pm 3,65$ & 0,001 \\
\hline Bulan ke-2 & $18,20 \pm 4,23$ & & $12,60 \pm 3,59$ & \\
\hline Bulan ke-0 & $14,60 \pm 4,37$ & $<0,001$ & $9,30 \pm 3,65$ & $<0,001$ \\
\hline Bulan ke-3 & $20,40 \pm 4,24$ & & $15,30 \pm 4,24$ & \\
\hline Bulan ke-1 & $15,10 \pm 4,22$ & $<0,001$ & $9,70 \pm 3,52$ & $<0,001$ \\
\hline Bulan ke-2 & $18,20 \pm 4,23$ & & $12,60 \pm 3,59$ & \\
\hline Bulan ke-2 & $18,20 \pm 4,23$ & & $12,60 \pm 3,59$ & 0,005 \\
\hline Bulan ke-3 & $20,40 \pm 4,24$ & & $15,30 \pm 4,24$ & \\
\hline
\end{tabular}

*Uji independent $t$ test; $\mathrm{p}<0,05$ bermakna; MMSE: Mini Mental State Examination; MoCA-Ina: Montreal Cognitive Assessment Versi Indonesia.

Penelitian lain untuk mengetahui efek donepezil terhadap gangguan kognitif kronik akibat cedera trauma kapitis mendapatkan bahwa donepezil meningkatkan setidaknya satu domain fungsi kognitif dan meningkatkan kemampuan dalam melakukan aktifitas sehari-hari serta dalam tingkat neuropsikologis. ${ }^{9-10} \mathrm{Hal}$ ini sesuai dengan penelitian ini, didapatkan perbaikan nilai MMSE yang bermakna pada kelompok terapi donepezil dan plasebo, yaitu pada orientasi dan recall setelah terapi donapezil. Demikian pula terdapat perbedaan yang bermakna hasil MoCA-Ina domain visuospasial dan delayed recall pascaterapi donapezil $(\mathrm{p}<0,05)$. Donepezil merupakan penghambat asetilkolinesterase, memiliki efek yang positif bermakna terhadap atensi dan memori. ${ }^{15-17}$

Sejauh ini penelitian untuk mengetahui hubungan donepezil dengan fungsi kognitif pada tumor intrakranial kebanyakan pada pascaradiasi. Castellino dkk menyimpulkan pemberian donepezil pada pasien tumor otak menunjukkan perbaikan fungsi eksekutif dan memori dengan efek toksisitas 
Tabel 4. Perbandingan Fungsi Kognitif antara Donepezil dan Plasebo (n=20)

\begin{tabular}{|c|c|c|c|c|c|}
\hline \multirow{2}{*}{ Variabel } & \multirow{2}{*}{ Terapi } & MMSE & \multirow{2}{*}{$\mathbf{p}^{*}$} & MoCA-Ina & \multirow{2}{*}{$\mathbf{p}^{*}$} \\
\hline & & Rerata \pm SD & & Rerata \pm SD & \\
\hline \multirow[t]{2}{*}{ Bulan ke-1 } & Donapezil & $15,10 \pm 4,22$ & 0,603 & $9,70 \pm 3,52$ & 0,869 \\
\hline & Plasebo & $13,90 \pm 5,78$ & & $10,00 \pm 4,42$ & \\
\hline \multirow[t]{2}{*}{ Bulan ke-2 } & Donapezil & $18,20 \pm 4,23$ & 0,062 & $12,60 \pm 3,59$ & 0,194 \\
\hline & Plasebo & $13,90 \pm 5,36$ & & $10,40 \pm 3,68$ & \\
\hline \multirow[t]{2}{*}{ Bulan ke-3 } & Donapezil & $20,40 \pm 4,24$ & 0,027 & $15,30 \pm 4,24$ & 0,024 \\
\hline & Plasebo & $15,20 \pm 5,32$ & & $10,80 \pm 3,88$ & \\
\hline
\end{tabular}

*Uji independent t test; $\mathrm{p}<0,05$ bermakna; MMSE: Mini Mental State Examination; MoCA-Ina: Montreal Cognitive Assessment Versi Indonesia.

Tabel 5. Deskripsi MMSE Sebelum dan Setelah Pemberian Donapezil dan Plasebo (n=20)

\begin{tabular}{|c|c|c|c|c|c|c|}
\hline Kelompok & MMSE & Waktu & $\mathbf{n}$ & $\operatorname{Rerata} \pm$ SD & $\begin{array}{c}\text { Median } \\
\text { (Min-Maks) }\end{array}$ & $\mathbf{p}$ \\
\hline \multirow[t]{10}{*}{ Donapezil } & \multirow[t]{2}{*}{ Orientasi } & Sebelum & 10 & $5,20 \pm 3,79$ & $5(0-10)$ & \multirow[t]{2}{*}{$0,017^{*}$} \\
\hline & & Setelah & 10 & $6,70 \pm 3,26$ & $7(2-10)$ & \\
\hline & \multirow[t]{2}{*}{ Registrasi } & Sebelum & 10 & $2,50 \pm 0,97$ & $3(0-3)$ & \multirow[t]{2}{*}{$0,180 * *$} \\
\hline & & Setelah & 10 & $2,90 \pm 0,31$ & $3(2-3)$ & \\
\hline & \multirow{2}{*}{$\begin{array}{l}\text { Atensi \& } \\
\text { Penamaan }\end{array}$} & Sebelum & 10 & $0,80 \pm 1,31$ & $0(0-4)$ & \multirow[t]{2}{*}{$0,066 * *$} \\
\hline & & Setelah & 10 & $1,50 \pm 1,35$ & $1,50(0-4)$ & \\
\hline & \multirow[t]{2}{*}{ Recall } & Sebelum & 10 & $0,60 \pm 0,96$ & $0(0-3)$ & \multirow[t]{2}{*}{$0,006^{*}$} \\
\hline & & Setelah & 10 & $2,90 \pm 0,31$ & $3(2-3)$ & \\
\hline & \multirow[t]{2}{*}{ Bahasa } & Sebelum & 10 & $5,50 \pm 2,32$ & $6(0-8)$ & \multirow[t]{2}{*}{$0,134 * *$} \\
\hline & & Setelah & 10 & $6,40 \pm 2,06$ & $6,50(2-9)$ & \\
\hline \multirow[t]{10}{*}{ Plasebo } & \multirow[t]{2}{*}{ Orientasi } & Sebelum & 10 & $5,70 \pm 3,88$ & $6(0-10)$ & \multirow[t]{2}{*}{$0,168 * *$} \\
\hline & & Setelah & 10 & $6,30 \pm 2,94$ & $7(2-10)$ & \\
\hline & \multirow[t]{2}{*}{ Registrasi } & Sebelum & 10 & $3 \pm 0,00$ & $3(3-3)$ & \multirow[t]{2}{*}{$1,000 * *$} \\
\hline & & Setelah & 10 & $3 \pm 0,00$ & $3(3-3)$ & \\
\hline & \multirow{2}{*}{$\begin{array}{l}\text { Atensi \& } \\
\text { Penamaan }\end{array}$} & Sebelum & 10 & $0,60 \pm 0,66$ & $0,50(0-2)$ & \multirow[t]{2}{*}{$0,564 * *$} \\
\hline & & Setelah & 10 & $0,70 \pm 0,48$ & $1(0-1)$ & \\
\hline & \multirow[t]{2}{*}{ Recall } & Sebelum & 10 & $0,20 \pm 0,42$ & $0(0-1)$ & \multirow[t]{2}{*}{$0,317 * *$} \\
\hline & & Setelah & 10 & $0,30 \pm 0,67$ & $0(0-2)$ & \\
\hline & \multirow[t]{2}{*}{ Bahasa } & Sebelum & 10 & $4,60 \pm 1,89$ & $5(2-8)$ & \multirow[t]{2}{*}{$0,081 * *$} \\
\hline & & Setelah & 10 & $4,90 \pm 1,79$ & $5(2-8)$ & \\
\hline
\end{tabular}

*Uji paired t test; **Uji Wilcoxon; $\mathrm{p}<0,05$ bermakna; MMSE: Mini Mental State Examination.

yang masih dapat ditoleransi. ${ }^{15}$ Shaw dkk mendapatkan bahwa donepezil meningkatkan fungsi kognitif, mood, serta kualitas hidup setelah pemberian selama 24 minggu dengan efek toksik yang minimal pada pasien tumor otak yang dilakukan radioterapi. ${ }^{7}$

Donepezil menjadi salah satu terapi yang sangat menjanjikan dikarenakan beberapa studi metilfenidat danmodafiniluntukmembantuperbaikanfungsikognitif memberikan hasil yang kurang memuaskan. ${ }^{5,10}$ Rapp dkk melakukan uji coba terkontrol plasebo fase III terhadap 198 subjek untuk menentukan peningkatan fungsi kognitif oleh donepezil pada pasien tumor otak primer dan metastasis yang dilakukan radioterapi parsial atau whole brain radiotherapy dengan dosis $\geq 30 \mathrm{~Gy}$. Pasien menerima donepezil $5 \mathrm{mg}$ selama enam minggu dilanjutkan $10 \mathrm{mg}$ selama 18 minggu, hingga total pemberian 24 minggu setelah menyelesaikan radioterapi. Hasilnya tidak didapatkan perbedaan dalam kognisi global, namun didapat perbaikan yang bermakna pada memori dan atensi. ${ }^{8}$ 
Tabel 6. Perbedaan Hasil MoCA-Ina Sebelum dan Setelah Donapezil dan Plasebo (n=20)

\begin{tabular}{|c|c|c|c|c|c|c|}
\hline Kelompok & MoCA-Ina & Waktu & $\mathbf{n}$ & $\operatorname{Rerata} \pm$ SD & $\begin{array}{c}\text { Median } \\
\text { (Min-Maks) }\end{array}$ & $\mathbf{p}$ \\
\hline \multirow[t]{14}{*}{ Donapezil } & \multirow[t]{2}{*}{ Visuospasial } & Sebelum & 10 & $0,80 \pm 0,63$ & $1(0-2)$ & $0,034 *$ \\
\hline & & Setelah & 10 & $1,40 \pm 0,69$ & $1,50(0-2)$ & \\
\hline & \multirow[t]{2}{*}{ Penamaan } & Sebelum & 10 & $2,20 \pm 1,13$ & $3(0-3)$ & $0,180 * *$ \\
\hline & & Setelah & 10 & $2,70 \pm 0,67$ & $3(1-3)$ & \\
\hline & \multirow[t]{2}{*}{ Atensi } & Sebelum & 10 & $2,40 \pm 1,07$ & $2(1-4)$ & $0,102 * *$ \\
\hline & & Setelah & 10 & $2,80 \pm 1,13$ & $2,50(1-4)$ & \\
\hline & \multirow[t]{2}{*}{ Bahasa } & Sebelum & 10 & $0,10 \pm 0,31$ & $0(0-1)$ & $0,063 * *$ \\
\hline & & Setelah & 10 & $0,70 \pm 0,82$ & $0,5(0-2)$ & \\
\hline & \multirow[t]{2}{*}{ Abstraksi } & Sebelum & 10 & $0,30 \pm 0,67$ & $0(0-2)$ & $0,180 * *$ \\
\hline & & Setelah & 10 & $0,60 \pm 0,84$ & $0(0-2)$ & \\
\hline & \multirow[t]{2}{*}{ Delayed Recall } & Sebelum & 10 & $0,40 \pm 0,69$ & $0(0-2)$ & $0,004 *$ \\
\hline & & Setelah & 10 & $3,70 \pm 1,16$ & $4(1-5)$ & \\
\hline & \multirow[t]{2}{*}{ Orientasi } & Sebelum & 10 & $3,20 \pm 2,15$ & $2,50(0-6)$ & $0,168 * *$ \\
\hline & & Setelah & 10 & $3,40 \pm 1,95$ & $3(1-6)$ & \\
\hline \multirow[t]{14}{*}{ Plasebo } & \multirow[t]{2}{*}{ Visuospasial } & Sebelum & 10 & $1,30 \pm 1,16$ & $1(0-3)$ & - \\
\hline & & Setelah & 10 & $1,30 \pm 1,16$ & $1(0-3)$ & \\
\hline & \multirow[t]{2}{*}{ Penamaan } & Sebelum & 10 & $1,70 \pm 0,94$ & $2(0-3)$ & - \\
\hline & & Setelah & 10 & $1,70 \pm 0,94$ & $2(0-3)$ & \\
\hline & \multirow[t]{2}{*}{ Atensi } & Sebelum & 10 & $1,90 \pm 1,19$ & $2(0-4)$ & $0,343 * *$ \\
\hline & & Setelah & 10 & $1,80 \pm 1,03$ & $2(0-3)$ & \\
\hline & \multirow[t]{2}{*}{ Bahasa } & Sebelum & 10 & $0,80 \pm 0,78$ & $1(0-2)$ & $1,000 * *$ \\
\hline & & Setelah & 10 & $0,80 \pm 0,78$ & $1(0-2)$ & \\
\hline & \multirow[t]{2}{*}{ Abstraksi } & Sebelum & 10 & $0,50 \pm 0,85$ & $0(0-2)$ & $0,317 * *$ \\
\hline & & Setelah & 10 & $0,60 \pm 0,84$ & $0(0-2)$ & \\
\hline & \multirow[t]{2}{*}{ Delayed Recall } & Sebelum & 10 & $0,50 \pm 0,70$ & $0(0-2)$ & $0,317 * *$ \\
\hline & & Setelah & 10 & $0,60 \pm 0,69$ & $0,50(0-2)$ & \\
\hline & \multirow[t]{2}{*}{ Orientasi } & Sebelum & 10 & $3,50 \pm 2,36$ & $4,50(0-6)$ & $0,343 * *$ \\
\hline & & Setelah & 10 & $4,00 \pm 1,15$ & $4(2-6)$ & \\
\hline
\end{tabular}

*Uji $t$ test berpasangan; **Uji Wilcoxon; $\mathrm{p}<0,05$ bermakna; MoCA-Ina: Montreal Cognitive Assessment Versi Indonesia.

Penelitian tentang dosis donepezil hidroklorida dan penyakit Alzheimer didapatkan peningkatan efektifitas yang lebih besar pada dosis yang lebih tinggi. ${ }^{6}$ Namun dosis yang lebih tinggi ini dikaitkan dengan efek samping yang lebih besar, antara lain pusing dan mengantuk akibat aktivasi asetilkolin dalam struktur retikular di pons. Dalam studi retrograd disebutkan efek samping minimal pada dosis 10 atau $5 \mathrm{mg} .^{6}$

Penelitian ini menggunakan dosis $5 \mathrm{mg}$ selama 12 minggu berdasarkan pengalaman klinis adanya efek samping pada pemberian $10 \mathrm{mg}$. Hal ini sekaligus untuk membuktikan bahwa dosis $5 \mathrm{mg}$ cukup untuk perbaikan fungsi kognitif pada kasus ini. Dalam kasus tidak adanya pengobatan yang efektif, seperti pada demensia pascaradioterapi, pendekatan berdasarkan patofisiologi menjadi penting dan pemberian terapi tersebut dapat meningkatkan kualitas kehidupan pasien. ${ }^{15}$

Penelitian ini mendapatkan perbaikan nilai MMSE dan MoCA-Ina semua subjek pada kelompok donepezil pada bulan ketiga. Studi eksperimental pada tikus menyimpulkan bahwa donepezil dapat meningkatkan fungsi kognitif dengan meningkatkan produksi insulin-like growth factor I pada hipokampus yang akan menstimulasi sensori neuron. Fungsi lain 
adalah donepezil sendiri mempertahankan saraf kolinergik pada septum medial dari neurodegenerasi pada bulbektomi saraf olfaktorius pada tikus dan memperbaiki fungsi kognitif secara bermakna. ${ }^{12-13}$ Adapun Wang dkk menyimpulkan donepezil tidak memengaruhi progresi dari deformitas hipokampus. ${ }^{14}$

Kotani dkk mendapatkan donepezil meningkatkan neurogenesis pada hipokampus yang didukung oleh penelitian lainnya bahwa donepezil menstabilisasi volume dari hipokampus. ${ }^{15}$ Donepezil juga dipercaya mengurangi degradasi sinaps serta memperbaiki perfusi pada kerusakan mikrovaskular. Selanjutnya, asetilkolin reseptor pada permukaan sel mikroglial menstimulasi kaskade selular yang menginhibisi respons inflamasi, melalui mekanisme yang membatasi kematian sel dan zat neurotoksis yang berasal dari proses inflamasi kronik. ${ }^{15,18}$

Penelitian ini juga memiliki kekurangan, yaitu jumlah subjek penelitian yang sedikit dan waktu evaluasi yang relatif singkat. Pada umumnya, evaluasi dilakukan selama enam bulan pemberian, sedangkan pada penelitian ini hanya selama tiga bulan.

Kekurangan lain adalah tidak ada data tentang tipe pembedahan, luas reseksi, ukuran tumor, serta tidak adanya keseragaman jarak waktu antara operasi dengan pemeriksaan fungsi kognitif dan pemberian donepezil. Demikian pula tidak ada penilaian sisa tumor pascaoperasi saat dilakukan penelitian, hanya 8 subjek yang sudah dilakukan MRI kepala evaluasi. Namun semua subjek penelitian ini dikatakan dilakukan reseksi total berdasarkan laporan operan, sehingga diasumsikan berada pada kondisi sisa tumor yang minimal saat dilakukan penelitian dan tidak memengaruhi perbedaan hasil. Hal ini dibuktikan dengan tidak adanya perburukan gejala klinis neurologis.

Walaupun demikian, penelitian ini dapat dijadikan data dasar penelitian tumor intrakranial selanjutnya. Selain akibat tumor itu sendiri, perlu juga ditelah lebih lanjut gangguan fungsi kognitif akibat tindakan radioterapi serta kemoterapi, serta pentingnya peran neurorehabilitasi.

\section{KESIMPULAN}

Terdapat perbaikan skoring MMSE dan MoCAIna pada pasien tumor intrakranial pascapembedahan dengan gangguan fungsi kognitif pascapemberian donepezil $5 \mathrm{mg}$ selama 3 bulan.

\section{DAFTAR PUSTAKA}

1. Omura A, Delattre J. Brain tumors and dementia. Handb Cllinical Neurol. 2008;89:877-85.

2. Day J, Gillespie D, Rooney A, Bulbeck HJ, Zienius K, Boele F. Neurocognitive deficits and neurocognitive rehabilitation in adult brain tumors. Curr Treat Options Neurol. 2016;18:1-22.

3. Felistia Y,DiansariY, Marisdina S, Erial Bahar. Gambaran fungsi kognitif pada pasien dengan tumor intrakranial di RSUP Dr. Mohammad Hoesin Palembang. Penelitian internal (Tidak dipublikasikan). 2017.

4. Wartena R, Brandsma D, Belderbos J. Are memantine, methylphenidate and donepezil effective in sparing cognitive functioning after brain irradiation? J Cancer Metastasis Treat. 2018;2018:4-11.

5. Sabbagh M, Han S, Kim S, Na H-R, Lee J-H, Kandiah $\mathrm{N}$, dkk. Clinical recommendations for the use of donepezil 23mg in moderate-to-severe Alzheimer's disease in the Asia-Pacific Region. Dement Geriatr Cogn Dis Extra. 2016;6(3):382-95.

6. Shaw E, McKee N, Case D, Lawrence J, Lesser G, Naughton M, dkk. Incidence of mild cognitive impairment in irradiated brain tumor survivors. Int J Radiat Oncol. 2014;90(1):162-3.

7. Meskal I, Gehring K, Rutten GJM, Sitskoorn MM. Cognitive functioning in meningioma patients: a systematic review. J Neurooncol. 2016;128(2):195-205.

8. Robinson G, Biggs V, Walker D. Cognitive screening in brain tumors: short but sensitive enough? Front Oncol. 2015;5(60):1-7.

9. Moca Test. MoCA Montreal Cognitive Assesment; 2019.

10. Crum RM, Anthony JC, Bassett SS, Folstein MF. Population-based norms for the Mini-Mental Status Examination by age and educational level. JAMA.1993;269(18):2386-91.

11. Aninditha T. Meningioma dan tumor meningeal lainnya. Buku Ajar Neuroonkologi. Jakarta; Penerbit Kedokteran Indonesia; 2019. h. 125-35.

12. Correa DD, Kryza-Lacombe M, Baser RE, Beal $\mathrm{K}$, DeAngelis LM. Cognitive effects of donepezil therapy in patients with brain tumors: a pilot study. J Neurooncol. 2016;127(2):313-9.

13. Yamamoto Y, Shioda N, Moriguchi S. Donepezil induced neuroprotection of acetylcholinergic neurons in olfactory bulbectomized mice. Curr Treat Options Neurol. 2010;130(5):717-21.

14. Wang L, Harms MP, Staggs J. Donepezil treatment and changes in hippocampal structure in very mild Alzheimer disease. Arch Neurol. 2010;67(1):99-106. 
15. Kotani S, Yamauchi T, Teramoto $T$, Ogura $H$. Donepezil, an acetylcholinesterase inhibitor, enhances adult hippocampal neurogenesis. Chem Biol Interact. 2008;175(1-3):227-30. 